\title{
The Mechanisms of Learning and the Survival of New Ventures
}

\author{
Deng Yingyu \\ Management Engineering Department \\ Harbin Institute of Technology Shenzhen Graduate School, P.R.China \\ (E-mail: gdyy1@126.com)
}

\begin{abstract}
There are two main activities in entrepreneurial process associated with the survival of new ventures: coping with the liabilities of newness and exploit competitive advantage. Entrepreneurship is a process of learning. Based on available research on entrepreneurship, we identify internal and external mechanisms of learning in new ventures and propose that the role of learning is highlighted as central as it provides entrepreneurs the possibility to improve their ability to to learn how to overcome traditional obstacles when organizing and managing new ventures (i.e., the liabilities of newness) and exploit competitive advantage in new venture.
\end{abstract}

Key word new venture, survival of new ventures, liabilities of newness, learning

\section{Introduction}

Although there is dispute amongst research scholars about How high the failure rate for new ventures is, It is generally acknowledged that starting a new business is a high-risk activity. Why do so many new ventures fail? The risks of failure facing a new venture are derived from several sources: including the costs of learning new tasks(Stinchcombe, 1965; Singhetal, 1986); the characteristics of the new product (Aldrich and Auster, 1986); the strength of conflicts regarding new organizational roles (Stinchcombe, 1965; Singhetal, 1986); the presence or absence of informal organizational structures (Stinchcombe, 1965); the stability of links with key stakeholders (Stinchcombe, 1965; Singh et al. 1986); and the degree of organizational stability/ inertia(Hannanand Freeman, 1984). Stinchcombe introduced the concept of the liability of newness to explain why more new ventures failed than did established businesses (Stinchcombe, 1965).

We consider the liability of newness on three separate dimensions, viz.: newness to themarket, newness to production, and newness to management. There is considerable agreement that the above factors contribute to the liability of newness and that the liability of newness declines over time. Researchers also found that the ability of an entrepreneur to implement actions that might allow them to more rapidly reduce mortality risk. Entrepreneurs often start a new venture ignorant of many key dimensions of running their businesses and must obtain the necessary knowledge If they are to survive. Some evolutionary scholars are optimistic that the acquisition of information and knowledge may improve a new organization's chances of adaptation and survival (Parkhe, 1991) and argue that positive results stem from learning derived from interactions among organizations (Davis, 1991; Burns and Wholey, 1993; Haunschild, 1993). The views of new venture's survival emphasis on the acquisition of knowledge, either by venture managers or by customers, suppliers, buyers, regulators, and others. It is critical for new ventures to succeed that heir managers obtain in knowledge and distribute it quickly and appropriately. They differ on what kownledge is required for survival and how easily it can be obtained.

We argue that mortality risk increases with the degree of newness in each dimension and with the number of dimensions in which the new venture is newness. We propose the decline in mortality risk occurs as the venture's liabilities of newness in each of the three dimensions is eroded by knowledge search and learning processes. Further, we suggest that the survival chances of new ventures can be enhance by building competitive advantage. Previous research investigates the activities organizations might undertake to acquire information or knowledge and whether this learning occurs at the population-level (Minerand and Haunschild, 1995), organization-level (Meziasand and Glynn, 1993). This paper investigates how The mechanisms of learning affects the survival of new ventures. We argue that learning strategies of new venture can be employed, the firm's chances of survival will increase monotonically. A series of learning strategies are proposed and their impact on coping with the liabilities of newness and exploiting competitive advantage is considered.

\section{The Mechanisms of Internal Learning and the Survival of New Ventures}


New venture managers may learn from past choices and experiences about how to perform better in the future. Sometimes, this learning can facilitate adaptation to changed environmental conditions-it is the strategic choices of managers that help define the environmental pressures a business faces and how it maneuvers to meet them. We propose that a new venture manager's learning from experience can impact strategic decisions and the liability of newness - new venture managers can affect his unique package of issues facing a new venture. We argue that coping with the liabilities of newness in new venture can significantly improve a new venture's chance of survival.

\subsection{Entrepreneurs' career experience and learning}

Previous research indicates that prior start-up experience provides tacit knowledge that facilitates decision-making about entrepreneurial opportunities under uncertainty and time pressure (Johannisson, Landström, \& Rosenberg, 1998; Sarasvathy, 2001). As a result, individuals with more start-up experience should see a given opportunity as more desirable than other individuals see it, and therefore be more likely to exploit it (Shane, 2003). Several empirical studies provide support for this "learning by doing" argument. For example, Gimeno, Folta, Cooper, and Woo (1997) showed that prior start-up experience enhances the economic performance of new ventures, suggesting that new ventures whose founders had more previous start-up experiences earn more income from their businesses. A previous start-up experience is, in addition, often considered to provide knowledge that helps an entrepreneur to overcome the liabilities of newness that new ventures face (Reuber \& Fischer, 1993; Shane \& Khurana, 2003; Starr \& Bygrave, 1992). Moreover, Cooper, Woo, and Dunkelberg (1989) showed that entrepreneurs' prior start-up experience had a significant and positive relationship with firm performance (see also Dyke, Fischer, \& Reuber, 1992; Stuart \& Abetti, 1990 for similar results). Several authors also point out that even if some of the information and knowledge can be learned through education, much of the necessary information about exploiting opportunities and in coping with the liabilities of newness can only be learned by doing (Cope \& Watts, 2000; Rae, 2000; Shane, 2003). For example, developing routines to form organizations may only be learned by creating organizations (Bruderl, Preisendorfer, \& Ziegler, 1992; Shepherd, Douglas, \& Shanley, 2000), and gathering the right information and making effective decisions about opportunities may be something that can only be understood by undertaking those activities (Duchesneau \& Gartne r, 1990; Ronstadt, 1988).

Another type of experience that has been highlighted in the literature on entrepreneurial learning is the entrepreneurs' amount of management experience. Several studies suggest that prior management experience increases an individual's intention to start a new venture, thereby facilitating the opportunity recognition process (e.g., Delmar \& Davidsson, 2000; Honig \& Davidsson, 2000; Vesalainen \& Pihkala, 1999). Hence, general management experience seems to provide individuals with information about many of the basic aspects of business that are relevant to recognize and act on entrepreneurial opportunities, such as finance, sales, technology, logistics, marketing, and organization (Romanelli \& Schoonhoven, 2001; Shepherd et al., 2000). Moreover, having prior management experience provides the entrepreneurs training in many of the skills needed for coping with the liabilities of newness, such as selling, negotiating, leading, planning, decision making, problem solving, organizing, and communicating (Lorrain \& Dussault, 1988; Shane, 2003).

Considering that entrepreneurs often face uncertainty about the value of the goods and services that they plan to produce, it seems fair to assume that also industry-specific experience can have a strong influence on their development of entrepreneurial knowledge (Shane, 2003; Shepherd et al., 2000). This implies that individuals with prior experience as a customer or supplier in an industry often have a better understanding of how to meet demand conditions in that marketplace, as industry experience provides information that outsiders cannot gather (Johnson, 1986). For example, Aldrich (1999) showed that founders tend to start businesses in industries in which they were previously employed, because their employment experience allows them to take advantage of information of the exploitation of opportunities gathered from their previous employment. Similarly, Cooper, Dunkelberg, and Woo's (1988) study shows that the products, services, customers, and suppliers of the surviving ventures were more closely related to the products, services, customers, and suppliers of the entrepreneurs' previous employer, than were those of the failing ventures (see also Bates \& Servon, 2000 for similar results).

Taken together, the literature seems to suggest at least three types of career experiences that are associated with entrepreneurial learning, start-up experience, management experience, and industry specific experience. Each of these types of experiences does seem likely to expose individuals to problems, which they might encounter in running a new venture, and hence facilitate acquisition of knowledge that would help solve similar problems in the future.

2.2 The internal learning and coping with the liabilities of newness 
An important ability of a successful entrepreneur is the ability to cope with liabilities of newness (Aldrich, 1999; Shepherd et al., 2000; Starr \& Bygrave, 1992; Stinchcombe, 1965). It is a well-known fact that the rate of mortality among newly founded firms is very high (Laitinen, 1992; Timmons, 1999). The main reasons for this rather sad statistics have been found to be inadequate funding and inefficient marketing (Storey, 1994; Sullivan, Warren, \& Westbrook, 1999). Potential customers have, for example, little basis for trusting newcomers without a sufficient track record because of their short operating histories, and buyers can hence be hesitant to place orders. The shortfall in cash flow can moreover reduce the ability of the new firm to adequately respond to outside problems and threats. Entrepreneurs must consequently earn the recognition that they are legitimate businesspersons by reliably providing goods and services in a timely manner. Financial problems as well as marketing problems seem consequently to be common reasons for the high failure rates among new ventures, and the average first-time entrepreneur seems to be ill equipped to handle the traditional obstacles and uncertainties related to setting up a new venture.

Previous experience could however lead to a greater likelihood of a customized set of benefits, such as relevant business skills, well-developed networks, and a business rep utation, that can be leveraged into subsequent ventures (Hudson \& McArthur, 1994; Shane \& Khurana, 2003; Shepherd et al., 2000; Starr \& Bygrave, 1992; Wright, Robbie, \& Ennew, 1997). The ability to better cope with liabilities of newness could in this respect involve several aspects related to the various ways entrepreneurs reduce the traditional obstacles and uncertainties related to setting up a new venture (Aldrich \& Auster, 1986; Shepherd et al., 2000; Starr \& Bygrave, 1992), such as finding financial start-up capital, legitimacy building, adaptation to changes, having access to social and business networks, etc. There can also be certain knowledge-based barriers to entry, meaning that a certain level of production technology or managerial capability is a prerequisite to meet the contextual constrains that new ventures face and the difficulties that managers have in overcoming them (Cohen \& Levinthal, 1990; Shepherd et al., 2000). A diverse background may, in this respect, stimulate creativity by associating to more linkages, which in turn provide a more robust basis for learning and development in new uncertain situations (Cohen \& Levinthal, 1990). Hence, it can be argued that previous experience provides entrepreneurs the opportunity to increase their ability to cope with the liabilities of newness, and learn new knowledge that can be readily redeployed in other ventures, and thereby provide them with the ability to enter into new markets, products, or technologies with greater success (Kolvereid \& Bullvåg, 1993; MacMillan, 1986; McGrath, 1999; Starr et al., 1993). An increased effectiveness to cope with the liabilities of newness seems, in this respect, to be manifested through the "wealth" that entrepreneurs have created in terms of financial facilities, the "power" they possess by exploiting their social networks, and the "legitimacy" they have acquired by developing a business reputation, which can help the entrepreneurs to secure financial resources and develop a market for their products or services (Starr \& Bygrave, 1992)

\section{The Mmechanisms of External Learning and the Survival of New Ventures}

Though most firms internally develop much of the knowledge used in innovation, few firms possess all the inputs required for successful and continuous technological development. Organizations often turn to external sources to fulfill their knowledge requirements (Rosenkopf and Nerkar, 2001). In fact, suppliers, buyers, universities, consultants, government agencies and competitors all serve as sources of vital knowledge (Jewkes et al., 1958). Research on organizational learning suggests that one source of technological knowledge available to firms is the exploitation of external knowledge for innovation (e.g. Cohen and Levinthal, 1990). Prior research also suggests that a variety of external mechanisms may be used to access this knowledge. These mechanisms include the hiring of scientists and engineers (Zucker, 1998; Almeida and Kogut, 1999), the forming of strategic alliances (Mowery et al., 1996; Rosenkopf and Almeida, 2001) and the appropriation of informal networks (Liebeskind et al., 1996; Almeida and Kogut, 1997; Rosenkopf and Tushman, 1998). Our understanding of the mechanisms of external knowledge sourcing has grown in recent years, we study four mechanisms of external knowledge acquisition - expert mobility, alliances, informal geographically mediated networks and Social interaction. We argue that while new venture may not only learn from formal mechanisms, such as alliances, but also learn from informal mechanisms, such as mobility. We proposal that knowledge acquisition in new venture will enhance exploitation processes of competitive advantage, by 
speeding up new product development, enhancing technological distinctiveness, and reducing sales costs.

\subsection{Alliances and learning}

Since Hamel and Doz (1989) first suggested that alliances should be viewed as learning opportunities, several studies have supported this idea (e.g. Gulati, 1995; Eisenhardt and Schoonhoven, 1996). For instance, Powell et al. (1996) postulate the existence of "networks of learning", and suggest that participation in networks of R\&D alliances facilitates the growth of new biotechnology firms. In-depth case studies also provide us with a rich illustration of learning between alliance or network partners (e.g. Inkpen and Crossan, 1995; Doz, 1996). Recent studies on alliances have used patent citation data to track knowledge flows across organizations and regions more directly and have suggested that alliances can lead to inter-firm learning (Mowery et al., 1996; Stuart and Podolny, 1996).

\subsection{Mobility and learning}

The notion that the mobility of people facilitates the flow of knowledge is hardly new. There are numerous studies relating the two, though most provide only indirect support for the idea that inter-firm mobility leads to inter-firm learning (e.g. Bell, 1984; Markusen et al., 1986; Malecki, 1991; Boeker, 1997). As was the case for alliance research, the most accessible direct evidence linking mobility of engineers to inter-firm knowledge building may be accomplished through patent records. Almeida and Kogut (1999) tracked over 400 engineers in a study of semiconductor firms, and showed that the mobility of engineers between firms in a region led to the localization of knowledge within the region, while the mobility of engineers across regions led to a decrease in regional knowledge.

\subsection{Geographic regions and learning}

Research points to the importance of geographically clustered social networks in facilitating the informal diffusion of knowledge across firms (Rogers and Larson, 1984). Case studies of regional clusters in Italy (Piore and Sabel, 1984) and Baden-Wuerttemberg in Germany (Herrigel, 1993) indicate extensive knowledge flows through networks in these regions. Locational proximity reduces the cost and increases the frequency of personal contacts, which serve to build social relations between players in a network (Dorfman, 1987; Saxenian, 1990; Almeida and Kogut, 1997) that can be appropriated for learning purposes.

\subsection{Social interaction and learning}

Greater levels of social interaction between a new venture and its key customer increase the knowledge new venture acquires through that relationship by intensifying role interactions (Ring and Van de Ven, 1994), by enhancing the firm's ability to recognize and evaluate pertinent knowledge (Cohen and Levinthal, 1990; Lane and Lubatkin, 1998), and by thence increasing its incentive to exchange and process information (Dyer and Singh, 1998; Larson, 1992; Zahra, Ireland, and Hitt, 2000). Larson (1992) and Ring and Van de Ven(1994) note that social interactions develop over time in dyadic relationships as exchange partners become comfortable with each other's competence and reliability in economic exchange. In turn, the more these social interactions build, the greater the intensity, frequency, and breadth of information exchanged. Lane and Lubatkin (1998) argued that while observable or explicit knowledge may be relatively easy to obtain through passive efforts such as reading trade journals or more active methods such as benchmarking, interactive learning allows a firm to get close enough to acquire not just the observable, but the deeper tacit components of knowledge (Kogut and Zander, 1996). Not only should social interaction facilitate knowledge acquisition by creating intense, repeated interaction, it should also provides better access to and understanding of the key customer's operations and more effective means of communicating with the key customer.

\subsection{External learning and exploiting competitive advantage}

The survival chances of new ventures can enhance by exploiting competitive advantage through new product development, technological distinctiveness and sales cost efficiency.

Organizations learn and create innovations through knowledge communication and combination (Schumpeter, 1934; Kogut and Zander, 1992). Successful new product development not only needs new knowledge but also requires inputs of relevant complementary knowledge (e.g., market, manufacturing, and design knowledge possessed by other firms). Even if technically possible, strictly in-house development of such complementary knowledge is often not economically feasible (Teece, 1986).In all, external knowledge acquisition increases new product development in three ways: (1) by enhancing the breadth and depth of relation-specific knowledge available to the firm, thereby increasing the potential for new innovative combinations; (2) by enhancing the speed of product development through reduced 
development cycles; (3) by increasing the willingness of the new technology-based firm to develop new products for its key customer.

Knowledge acquisition from difference external learning will enhance both the depth and breadth of knowledge available to the focal firm; such knowledge is critical to the development of technology with benefits distinct from those of competitors. Greater depth of knowledge, especially knowledge acquired via interactions with customers, enhances the ability to conceive and realize significant product differentiation (Zahra et al., 2000). Richer and more varied knowledge can also be used to upgrade products, to increase customer specialization, and to understand competing and complementary technologies, thus enhancing the distinctiveness of the focal firm's technology. In short, greater external knowledge acquisition from the key customer enhances the new technology-based firm's understanding of market needs, leading to more distinctive and competitive technologies.

Improvement in organizational efficiency is perhaps the most studied outcome of organizational learning (Argote, 1999). Research into the learning curve provides evidence that the costs of Producing manufactured items decrease with the cumulative number of items produced (Yelle1979). The benefits of the learning curve may also benefit organizations in ways unrelated to production costs, such as higher quality, more effective pricing decisions, and marketing (Besanko et al. 1997). Learning from difference external sources may result in such benefits as design economies, inbound or outbound logistics economies, or even manufacturing economies. Innovations resulting from new external knowledge thus extend beyond product enhancements and differentiation. In a external relationship, efficiency gains will be demonstrated as a reduction in the sales costs for the new technology-based firm.

\section{Conclusion}

Although scholars have long recognized the increased mortality risk that new ventures face in terms of a"liability of newness," most of the discussion around this risk has been in terms of the contextual constraints that new ventures face and the difficulties that managers have in overcoming them. Due to the research interest in new venture survival and the practical importance of increased understanding in the causes of failure and the actions that can be taken to reduce it, this article synthesized available research into a conceptual framework to enhance our understanding of the survival of new ventures at the organization level and investigates the relationship between mechanisms of learning and the liability of newness and exploit competitive advantage.Learning in new venture is often described as a continuous process that facilitates the development of necessary knowledge for being effective in starting up and managing new ventures. Based on available research on entrepreneurship, we identify internal and external mechanisms of learning in new ventures and proposal that the role of learning is highlighted as central as it provides entrepreneurs the possibility to improve their ability to to learn how to overcome traditional obstacles when organizing and managing new ventures (i.e., the liabilities of newness) and exploit competitive advantage in new venture.

\section{Reference}

[1] Almeida, P., Kogut, B., 1999. Localization of knowledge and the mobility of engineers in regional networks. Management Science 45 (7), 905-917.

[2] Argote L. 1999. Organizational Learning: Creating, Retaining and Transferring Knowledge. Kluwer: Boston, MA.

[3] Boeker, W., 1997. Executive migration and strategic change: the effect of top manager movement on product-market entry. Administrative Science Quarterly 42 (2), 213-236.

[4] Cope, J. \& Watts, G. (2000). Learning by doing. An exploration of experience, critical incidents and reflection in entrepreneurial learning. International Journal of Entrepreneurial Behaviour \& Research, 6(3), 104-124.

[5] Cohen, W.M., Levinthal, D.A., 1990. Absorptive capacity: a new perspective on learning and innovation. Administrative Science Quarterly 35 (1), 128-152.

[6] Dyer JH, Singh H. 1998. The relational view: cooperative strategy and sources of interorganizational competitive advantage. Academy of Management Review 23: 660-679.

[7] Hitt MA, Dacin MT, Levitas E, Arregle J-L, Borza A. 2000. Partner selection in emerging and developed market contexts: resource-based and organizational learning perspectives. Academy of Management Journal 43: 449-467.

[8] Kogut B, Zander U. 1992. Knowledge of the firm, combinative capabilities, and the replication of 
technology. Organization Science 3: 383-397.

[9] Larson A. 1992. Network dyads in entrepreneurial settings: a study of the governance of exchange relationships. Administrative Science Quarterly 37: 76-104.

[10] Lane PJ, Lubatkin M. 1998. Relative absorptive capacity and interorganizational learning. Strategic Management Journal 19(5): 461-477.

[11] Minniti, M. \& Bygrave, W. (2001). A dynamic model of entrepreneurial learning. Entrepreneurship Theory and Practice, 25(3), 5-16.

[12] Powell, W.W., Koput, K.W., et al., 1996. Interorganizational collaboration and the locus of innovation: networks of learning in biotechnology. Administrative Science Quarterly 41 (1), 116145.

[13] Rae, D. \& Carswell, M. (2001). Towards a conceptual understanding of entrepreneurial learning. Journal of Small Business and Enterprise Development, 8(2), 150-158.

[14] Ravasi, D., Turati, C., Marchisio, G., \& Ruta, C.D. (2004). Learning in entrepreneurial firms: An exploratory study. In G. Corbetta, M. Huse, \& D. Ravasi (Eds), Crossroads of entrepreneurship (pp. 165-184). Boston, MA: Kluwer Academic Publishers.

[15] Rosenkopf, L., Nerkar, A., 2001. Beyond local search: boundary-spanning, exploration, and impact in the optical disc industry. Strategic Management Journal 22 (4), 287-306.

[16] Rosenkopf, L., Metiu, A., George, V., 2001. From the bottom up? Technical committee activity and alliance formation. Administrative Science Quarterly 46 (4), 748-772.

[17] Rogers, E.M., Larson, J.K., 1984. Silicon Valley Fever: Growth of High-Technology Culture. Basic Books, New York.

[18] Shane, S. \& Khurana, R. (2003). Bringing individuals back in: The effects of career experience on new firm founding. Industrial and Corporate Change, 12(3), 519-543.

[19] Shook, C.L., Priem, R.L., \& McGee, J.E. (2003). Venture creation and the enterprising individual: A review and synthesis. Journal of Management, 29(3), 379-399.

[20] Zahra SA, Ireland RD, Hitt MA. 2000. International expansion by new venture firms: international diversity, mode of market entry, technological learning and performance. Academy of Management Journal 43: 925-950. 